\title{
Advanced cerebral monitoring in neurocritical care
}

\author{
Nobl Barazangi, J. Claude Hemphill III \\ Department of Neurology, University of California, San Francisco and Neurocritical Care Program, San Francisco General Hospital, \\ California, USA
}

\begin{abstract}
New cerebral monitoring techniques allow direct measurement of brain oxygenation and metabolism. Investigation using these new tools has provided additional insight into the understanding of the pathophysiology of acute brain injury and suggested new ways to guide management of secondary brain injury. Studies of focal brain tissue oxygen monitoring have suggested ischemic thresholds in focal regions of brain injury and demonstrated the interrelationship between brain tissue oxygen tension $\left(\mathrm{P}_{\mathrm{bt}} \mathrm{O}_{2}\right)$ and other cerebral physiologic and metabolic parameters. Jugular venous oxygen saturation $\left(\mathrm{SjVO}_{2}\right)$ monitoring may evaluate global brain oxygen delivery and consumption, providing thresholds for detecting brain hypoperfusion and hyperperfusion. Furthermore, critically low values of $\mathrm{P}_{\mathrm{bt}} \mathrm{O}_{2}$ and $\mathrm{SjVO}_{2}$ have also been predictive of mortality and worsened functional outcome, especially after head trauma. Cerebral microdialysis measures the concentrations of extracellular metabolites which may be relevant to cerebral metabolism or ischemia in focal areas of injury. Cerebral blood flow may be measured in the neurointensive care unit using continuous methods such as thermal diffusion and laser Doppler flowmetry. Initial studies have also attempted to correlate findings from advanced neuromonitoring with neuroimaging using dynamic perfusion computed tomography, positron emission tomography, and Xenon computed tomography. Additionally, new methods of data acquisition, storage, and analysis are being developed to address the increasing burden of patient data from neuromonitoring. Advanced informatics techniques such as hierarchical data clustering, generalized linear models, and heat map dendrograms are now being applied to multivariable patient data in order to better develop physiologic patient profiles to improve diagnosis and treatment.
\end{abstract}

Key words: Brain tissue oxygen tension, cerebral blood flow, cerebral microdialysis, cerebral neuromonitoring, jugular venous oxygen saturation, secondary brain injury, stroke, subarachnoid hemorrhage, traumatic brain injury

\section{Introduction}

Monitoring the brain after acute injury is central to the practice of neurocritical care for patients with a wide range of disorders including traumatic brain injury (TBI), ischemic and hemorrhagic stroke, as well as status epilepticus and acute brain infections. While historically the most widely available monitor has been the bedside clinical neurological examination, there has long been recognition that additional measures of intracranial pressure (ICP) and cerebral metabolism may augment clinical assessment or even supersede it. Current neuromonitoring techniques involve a range of tools that have evolved from the study of cerebral physiology and advances in the understanding of the pathophysiology of acute brain injury. These techniques have focused on the measurement of cerebral physiologic and metabolic parameters with the goal of improving the detection and management of primary and secondary brain injury in patients who have suffered TBI, stroke, subarachnoid hemorrhage $(\mathrm{SAH})$, or have had neurosurgical procedures. ${ }^{[1-3]}$ Some neuromonitoring techniques have been available for many years and have become established tools in the care of neurocritically ill patients, such as ICP and cerebral perfusion pressure (CPP) monitoring and electroencephalography (EEG). ${ }^{[1,4-6]}$ Our improved understanding of cellular and molecular disturbances that occur post-injury, in addition to technological advancements that allow for continuous, quantitative, and 'real-time' measurements, has led to the development of newer techniques that can detect cerebral metabolic disturbances, such as brain tissue oxygen monitoring and cerebral microdialysis..$^{[1-3,6-8]}$

The development of new neuromonitoring techniques has been particularly important because standard monitoring techniques, such as ICP and CPP measurements, may be insufficient in detecting subtle manifestations of brain injury or are poor 
surrogates for physiologic parameters of interest. For example, CPP may not be a reliable method to measure cerebral blood flow. ${ }^{[6,9]}$ The more recently developed neuromonitoring techniques reviewed here, including cerebral blood flow (CBF) monitoring techniques, brain tissue oxygen tension $\left(\mathrm{P}_{\mathrm{bt}} \mathrm{O}_{2}\right)$ and jugular bulb venous oxygen saturation $\left(\mathrm{SjVO}_{2}\right)$ monitoring, and cerebral microdialysis, may provide more detailed information regarding cerebral metabolic function. Ideally, these measurements would provide information that is of prognostic utility as well as help direct management of the neurocritically ill patient in order to improve clinical outcome. Even as many of these tools are now becoming integrated into regular neurocritical care, research is ongoing to determine the validity, reliability, and utility of these techniques in the clinical management of patients and in predicting and potentially improving clinical outcome. ${ }^{[2]}$

Additionally, as new neuromonitors have increased the volume and complexity of data available for assessment and management of the neurocritically ill patient, questions regarding methods of interpretation of this new data have justifiably arisen. It is becoming increasingly evident that our initial approaches to neuromonitoring, where information obtained from a single modality is interpreted independently from other cerebral and systemic physiologic and metabolic parameters, are likely overly simplistic. New methods of data collection and analysis, as well as advanced informatics techniques, are currently being developed to learn how to logically integrate neuromonitoring data, and have proven to be useful in discovering new interpretations of previously collected data. ${ }^{[3,7]}$

\section{Brain tissue oxygen monitoring}

The new advanced neuromonitoring opportunity with which there is the most familiarity is the ability to directly measure brain tissue oxygen tension $\left(\mathrm{P}_{\mathrm{bt}} \mathrm{O}_{2}\right)$. $\mathrm{P}_{\mathrm{bt}} \mathrm{O}_{2}$ monitoring allows direct measurement of focal tissue oxygen tension in a specific region of the brain. This presumably provides a measure of oxygen content or delivery which may be relevant in the assessment of secondary brain injury due to ischemia or impaired microvascular perfusion [Figure 1]. ${ }^{[10,11]}$ Two principal devices have been used in recent studies: the LICOX system (Integra Neurosciences, Plainsboro, NJ) which uses a polarograpic Clarke-type microelectrode and the NeuroTrend system (Codman and Shurtleff, Raynham, MA) which uses optical luminescence. However, the LICOX system (Integra Neurosciences, Plainsboro, $\mathrm{NJ}$ ) is currently the only commercially available $\mathrm{P}_{\mathrm{bt}} \mathrm{O}_{2}$ monitoring system. In this system, the $\mathrm{P}_{\mathrm{bt}} \mathrm{O}_{2}$ probe is placed directly into the brain parenchyma usually with a fixed cranial bolt, approximately $2-3 \mathrm{~cm}$ below the dura, targeting frontal white matter. Brain temperature is measured concurrently with the same probe. Optimal probe placement location remains a point of controversy. Our approach is to place the probe in the hemisphere ipsilateral to a focal injury (such as non-traumatic ICH or a region at risk for vasospasm after aneurysmal SAH) and place the probe in the least injured hemisphere in the context of diffuse injury such as with head trauma [Figure 2]. ${ }^{[10,12,13]}$

Interpretation and clinical application of $\mathrm{P}_{b t} \mathrm{O}_{2}$ monitoring data continues to be investigated; however, numerous observational studies have suggested specific $\mathrm{P}_{\mathrm{bt}} \mathrm{O}_{2}$ thresholds which may be associated with worsened outcome after TBI and SAH, and in other forms of brain injury as well. ${ }^{[10,14,15]}$ Initial impressions were that $\mathrm{P}_{\mathrm{bt}} \mathrm{O}_{2}$ monitoring would provide a specific diseaseindependent ischemic threshold. However, this has been shown to likely be an oversimplification as $\mathrm{P}_{b t} \mathrm{O}_{2}$ may vary with a number of physiological parameters such as inspired oxygen concentration $\left(\mathrm{F}_{\mathrm{i}} \mathrm{O}_{2}\right), \mathrm{CBF}$, and perhaps cerebral perfusion pressure. Even so, a $\mathrm{P}_{\mathrm{bt}} \mathrm{O}_{2}$ level below 10-15 mmHg has generally been the threshold identified at which outcome is worsened and some authors have referred to this as an "ischemic threshold." One study using positron emission tomography (PET) suggested a $\mathrm{P}_{\mathrm{bt}} \mathrm{O}_{2}$ of $14 \mathrm{mmHg}$ as the threshold at which critical oxygen extraction occurs. ${ }^{[16]}$

Several experimental studies have assessed the correlation of $\mathrm{P}_{\mathrm{bt}} \mathrm{O}_{2}$ with other measures of brain oxygenation such as jugular bulb venous oxygen saturation. ${ }^{[10,11,13,17]}$ Finding a clear-cut relationship between $\mathrm{P}_{b t} \mathrm{O}_{2}$ and $\mathrm{CBF}$ and cerebral oxygen extraction, which are important factors in determining cerebral metabolic rate of oxygen $\left(\mathrm{CMRO}_{2}\right)$, has been more challenging. $\mathrm{P}_{b t} \mathrm{O}_{2}$ measurements have been shown to positively correlate with arterial oxygen tension, $\mathrm{F}_{\mathrm{i}} \mathrm{O}_{2}$, mean arterial pressure, CPP, CBF, hemoglobin concentration, and inversely with oxygen extraction fraction on PET and mean transit time on dynamic CT perfusion (CTP). ${ }^{[10,14,18]}$ Experimental studies have shown a linear correlation between $\mathrm{P}_{\mathrm{bt}} \mathrm{O}_{2}$ and changes in end-tidal carbon dioxide measurements or CBF, and a sinusoidal correlation with mean arterial pressure, suggesting that $\mathrm{P}_{\mathrm{bt}} \mathrm{O}_{2}$ is influenced by factors that regulate $\mathrm{CBF}$ and cerebral autoregulation. ${ }^{[19]}$ Furthermore, hyperventilation has been shown to decrease $\mathrm{P}_{b t} \mathrm{O}_{2}$ and this is presumably mediated through a primary reduction in CBF due to cerebral vasoconstriction. ${ }^{[20-}$ ${ }^{22]}$ Poor oxygen reactivity testing, in which $\mathrm{P}_{\mathrm{bt}} \mathrm{O}_{2}$ does not increase to the expected degree in response to an increase in $\mathrm{F}_{\mathrm{i}} \mathrm{O}_{2}$, may indicate poor autoregulation and be associated with worsened outcome. ${ }^{[10,23]}$ Data is varied regarding the relationship between $\mathrm{P}_{b t} \mathrm{O}_{2}$ and ICP; in general $\mathrm{P}_{\mathrm{bt}} \mathrm{O}_{2}$ decreases with increased ICP only when CPP is concurrently decreased, suggesting that $\mathrm{P}_{b t} \mathrm{O}_{2}$ relates principally to measures of cerebral perfusion. ${ }^{[10,14,16,24]}$ Significantly decreased $\mathrm{P}_{\mathrm{bt}} \mathrm{O}_{2}$ has 


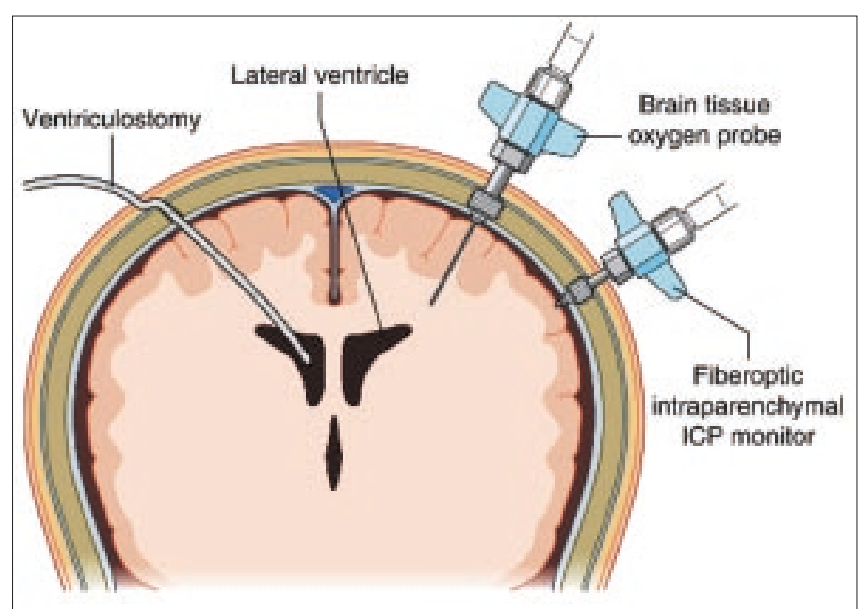

Figure 1: Schematic representation of a coronal section through the brain at the level of the third ventricle, demonstrating a ventriculostomy drain inserted into the lateral ventricle, an intraparenchymal brain tissue oxygen probe, and an intraparenchymal intracranial pressure monitor. (From: Hemphill JC and Smith WS. Neurologic Critical Care, Including Hypoxic-Ischemic Encephalopathy and Subarachnoid Hemorrhage. In: Fauci, AS, Braunwald E, Kaspar DL, Hauser SL, Longo DL, Jameson JL, and Loscalzo J, editors. Harrison's Principles of Internal Medicine. 17th ed. New York: McGraw-Hill; 2008. pp.1722. (Reproduced with permission of The McGraw-Hill Companies))

been correlated to an elevated lactate/pyruvate ratio in addition to other biochemical alterations found during cerebral microdialysis, but a consistent $\mathrm{P}_{\mathrm{bt}} \mathrm{O}_{2}$ threshold at which deleterious effects in cerebral metabolism occur remains elusive. ${ }^{[13,25-28]}$ Because CBF may be low in the setting of flow-metabolism uncoupling due to the primary injury or the administration of sedative medications, a low $\mathrm{P}_{b t} \mathrm{O}_{2}$ does not always mean ischemia (e.g., induced hypometabolism) and a high $\mathrm{P}_{\mathrm{bt}} \mathrm{O}_{2}$ may be pathologically abnormal (e.g., hyperemia). ${ }^{[10]}$ This suggests that $\mathrm{P}_{b t} \mathrm{O}_{2}$ must be considered in the context of other physiological parameters rather than necessarily superseding other values.

While many observational studies have investigated the relationship between $\mathrm{P}_{b t} \mathrm{O}_{2}$ and clinical outcome in patients with TBI, SAH, and, to a lesser extent, intracerebral hemorrhage (ICH), it is important to recognize that to date no randomized, controlled trials have been performed to assess the impact of $\mathrm{P}_{b t} \mathrm{O}_{2}$ monitoring or $\mathrm{P}_{b t} \mathrm{O}_{2}$-directed therapy on clinical outcome [Table 1]. Several studies in patients with TBI have shown that patients with $\mathrm{P}_{b t} \mathrm{O}_{2}$ levels less than 10-15 mmHg for extended periods of time or on multiple occasions have an increased rate of morbidity and mortality. ${ }^{[29-32]}$ The finding of a dose-response relationship in which duration and severity of low $\mathrm{P}_{\mathrm{bt}} \mathrm{O}_{2}$ is associated with long-term mortality suggests that low $\mathrm{P}_{\mathrm{bt}} \mathrm{O}_{2}$ is a reasonable target for intervention. ${ }^{[30]}$ Additionally, in one study patients with severe TBI who were managed with $\mathrm{P}_{\mathrm{bt}} \mathrm{O}_{2}$-guided therapy (goal $\mathrm{P}_{\mathrm{bt}} \mathrm{O}_{2}>25 \mathrm{mmHg}$ ) had a lower risk of mortality than historical controls managed with conventional ICP and CPP monitoring. However, it remains unclear

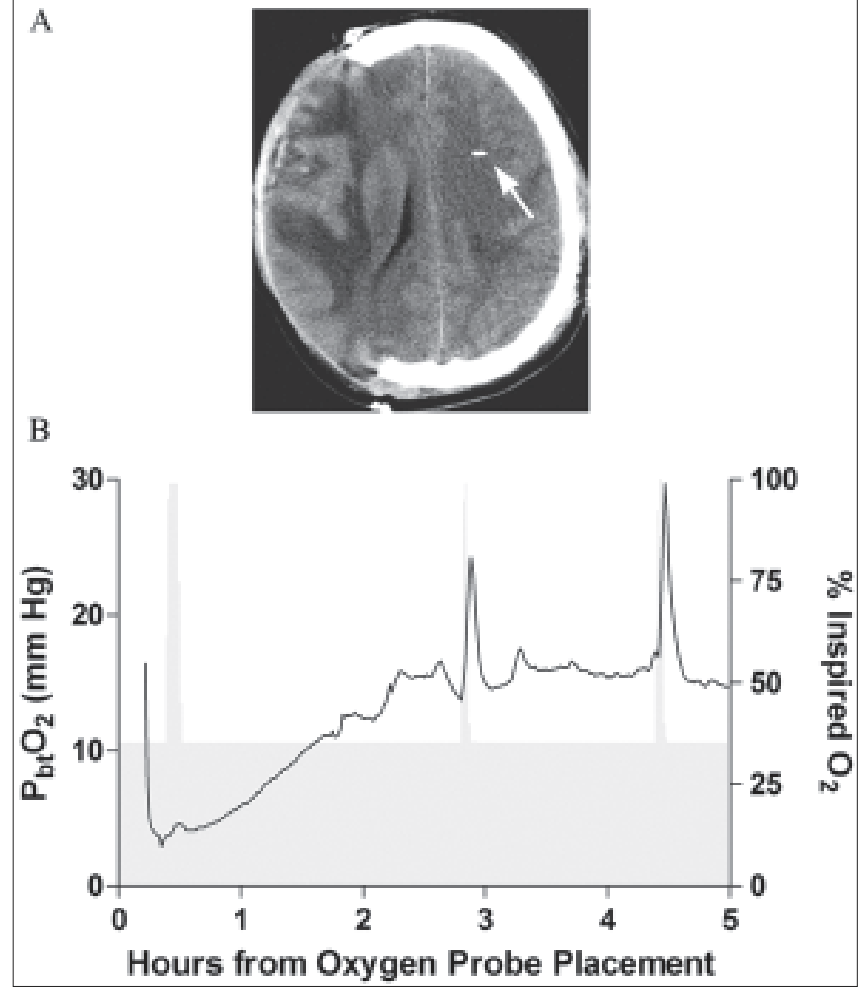

Figure 2: Representative non-contrast head computed tomography (CT) scan showing $\mathrm{P}_{\mathrm{bt}} \mathrm{O}_{2}$ monitor placement and $\mathrm{P}_{\mathrm{bt}} \mathrm{O}_{2}$ levels over time in two separate patients. (A), Non-contrast head CT from a patient with traumatic brain injury demonstrating the tip of the brain tissue oxygen probe (white arrow) in the left hemisphere white matter. $(\mathrm{B}), \mathrm{P}_{\mathrm{bt}} \mathrm{O}_{2}$ profile early after placement in a patient with intracerebral hemorrhage (probe placed ipsilateral to hematoma). Continuous $\mathrm{P}_{\mathrm{bt}} \mathrm{O}_{2}$ levels are shown; values are not considered reliable until stabilization at 1-2 h post-placement. The shaded region represents inspired oxygen concentration. Increases in per cent inspired oxygen to $100 \%$ results in an appropriate increase in the $\mathrm{P}_{\mathrm{bt}} \mathrm{O}_{2}$ level, indicating a functioning probe

whether this improvement was related exclusively to cerebral oxygenation or whether it might reflect overall improvements in neurocritical care. Other similar studies showed an equivocal response in outcome to $\mathrm{P}_{b t} \mathrm{O}_{2}$-guided therapy. ${ }^{[33,34]}$ Correlations between lower $\mathrm{P}_{b t} \mathrm{O}_{2}$ levels and poor performance on neuropsychological and cognitive testing after head trauma have also been observed. ${ }^{[35]}$ In aneurysmal $\mathrm{SAH}$, oxygen reactivity index (ORx), defined as a moving correlation coefficient between CPP and $\mathrm{P}_{b t} \mathrm{O}_{2}$, was predictive of symptomatic vasospasm whereas absolute values of ICP, CPP, and $\mathrm{P}_{\mathrm{bt}} \mathrm{O}_{2}$ were not. ${ }^{[36]}$ Taken together, this growing collection of evidence strongly suggests that $\mathrm{P}_{b t} \mathrm{O}_{2}$ levels are associated with short-term events of impaired cerebral oxygenation and long-term clinical outcome. However, in order for the field of advanced neuromonitoring to take the next substantial step forward, prospective controlled clinical trials are necessary to demonstrate that $\mathrm{P}_{\mathrm{bt}} \mathrm{O}_{2}$ is not just a prognostic marker, but rather a modifiable factor which can lead to improved outcome.

Drawbacks associated with $\mathrm{P}_{\mathrm{bt}} \mathrm{O}_{2}$ monitoring include the fact that $\mathrm{P}_{\mathrm{bt}} \mathrm{O}_{2}$ is a focal measure and may be influenced by probe location, although placement in the relatively 


\begin{tabular}{|c|c|c|c|c|c|}
\hline Study & Disorder & $\begin{array}{l}\text { Number of } \\
\text { patients }\end{array}$ & Method & Threshold & Outcome \\
\hline $\begin{array}{l}\text { Gopinath, et al.; } \\
1994\end{array}$ & $\mathrm{TBI}$ & 167 & $\mathrm{SjvO}_{2}$ & $<50 \%$ for more than $10 \mathrm{~min}$ & $\begin{array}{l}\text { Early } \mathrm{SjvO}_{2} \text { desaturations were significantly } \\
\text { related to poor neurological outcomes ( } 90 \% \text { of } \\
\text { patients with multiple desaturations, } 74 \% \text { of } \\
\text { patients with one desaturation, compared to } \\
55 \% \text { of patients without desaturations) }\end{array}$ \\
\hline $\begin{array}{l}\text { Robertson, et al.; } \\
1995\end{array}$ & TBI & 177 & $\mathrm{SjvO}_{2}$ & $<50 \%$ & $\begin{array}{l}\text { One or more episode of desaturation was } \\
\text { strongly associated with poor neurological } \\
\text { outcome }\end{array}$ \\
\hline $\begin{array}{l}\text { Keining, et al.; } \\
1997\end{array}$ & $\mathrm{TBI}, \mathrm{ICH}$ & $\begin{array}{l}21 \mathrm{TBI} \\
2 \mathrm{ICH}\end{array}$ & $\mathrm{P}_{\mathrm{bt}} \mathrm{O}_{2}$ & $<10 \mathrm{mmHg}$ & $\begin{array}{l}\text { Ischemic episode of }<10 \mathrm{mmHg} \text { for }>15 \mathrm{~min} \\
\text { always associated with poor neurological } \\
\text { outcome }\end{array}$ \\
\hline $\begin{array}{l}\text { Valadka, et al.; } \\
1998\end{array}$ & $\mathrm{TBI}$ & 43 & $\mathrm{P}_{\mathrm{bt}} \mathrm{O}_{2}$ & $<15 \mathrm{mmHg}$ & $\begin{array}{l}\text { The longer duration of } \mathrm{P}_{\mathrm{bt}} \mathrm{O}_{2}<15 \mathrm{mmHg} \text {, or } \\
\text { any duration of } \mathrm{P}_{\mathrm{bt}} \mathrm{O}_{2}<6 \mathrm{mmHg} \text {, the greater } \\
\text { likelihood of death }\end{array}$ \\
\hline $\begin{array}{l}\text { Bardt, et al.; } \\
1998\end{array}$ & TBI & 35 & $\mathrm{P}_{\mathrm{bt}} \mathrm{O}_{2}$ & $<10 \mathrm{mmHg}$ & $\begin{array}{l}56 \% \text { patients with } \mathrm{P}_{\mathrm{bt}} \mathrm{O}_{2}<10 \mathrm{mmHg} \text { for }>300 \\
\text { min died, } 22 \% \text { had poor outcome, } 22 \% \text { had } \\
\text { favorable outcome at six months }\end{array}$ \\
\hline $\begin{array}{l}\text { Dings, et al.; } \\
1998\end{array}$ & $\mathrm{TBI}$ & 35 & $\mathrm{P}_{\mathrm{bt}} \mathrm{O}_{2}$ & $<10 \mathrm{mmHg}$ & $\begin{array}{l}35.5 \% \text { of patients with bad outcome (GOS } 1-3 \\
\text { at six months) had } \mathrm{P}_{\text {bt }} \mathrm{O}_{2}<10 \mathrm{mmHg} \text { in first } \\
24 \mathrm{~h} \text {, compared to } 10.6 \% \text { in good outcome } \\
\text { group (GOS } 4-5 \text { at six months) }\end{array}$ \\
\hline $\begin{array}{l}\text { Cruz, et al.; } \\
1998\end{array}$ & TBI & $\begin{array}{l}178\left(\mathrm{SjvO}_{2}\right. \\
\text { group), } 175 \\
\text { (CPP group) }\end{array}$ & $\mathrm{SjvO}_{2}$ & $<50 \%$ & $\begin{array}{l}\text { Patients with additional SjvO2 monitoring had } \\
\text { improved mortality and outcome (GOS) } \\
\text { compared to patients with only CPP monitoring } \\
\text { (historical controls) }\end{array}$ \\
\hline $\begin{array}{l}\text { Cormio, et al.; } \\
1999\end{array}$ & TBI & $\begin{array}{l}450(19.1 \% \\
\text { had } \mathrm{SjvO}_{2}> \\
75 \mathrm{mmHg})\end{array}$ & $\mathrm{SjvO}_{2}$ & $>75 \%$ & $\begin{array}{l}\text { Patients with } \mathrm{SjvO}_{2}>75 \% \text { had a significantly } \\
\text { increased risk of death, persistent vegetative } \\
\text { state, or severe disability than in patients with } \\
\text { normal } \mathrm{SjvO}_{2}\end{array}$ \\
\hline $\begin{array}{l}\text { Van der Brink, et al.; } \\
2000\end{array}$ & TBI & 101 & $\mathrm{P}_{\mathrm{bt}} \mathrm{O}_{2}$ & $<5,10,15 \mathrm{mmHg}$ & $\begin{array}{l}\text { All } \mathrm{P}_{b t} \mathrm{O}_{2} \text { levels associated with poor outcome } \\
(\mathrm{GOS}) \text {, and relative risk of death increases } \\
\text { with lower } \mathrm{P}_{\mathrm{bt}} \mathrm{O}_{2} \text { thresholds }\end{array}$ \\
\hline Vath, et al.; 2001 & TBI & 51 & $\mathrm{P}_{\mathrm{bt}} \mathrm{O}_{2}$ & $<5 \mathrm{mmHg}$ & $\begin{array}{l}\text { PbtO2 }<5 \mathrm{mmHg} \text { significantly related to poor } \\
\text { outcome (GOS 1-3) at }<96 \mathrm{~h} \text { after trauma }\end{array}$ \\
\hline $\begin{array}{l}\text { Macmillan, et al.; } \\
2001\end{array}$ & TBI & 75 & $\mathrm{SjvO}_{2}$ & $>75 \%$ or $<54 \%$ & $\begin{array}{l}\text { Larger proportion of patients with poor } \\
\text { outcome (GOS 1-3) at } 12 \text { months had a } \mathrm{SjvO}_{2} \\
\text { level of }<54 \% \text { or }>75 \% \text { for longer duration than } \\
\text { those with good outcome (GOS 4-5) }\end{array}$ \\
\hline $\begin{array}{l}\text { van Santbrink, et al.; } \\
2003\end{array}$ & TBI & 41 & $\begin{array}{l}\mathrm{P}_{\mathrm{bt}} \mathrm{O}_{2} \\
/ \mathrm{TOR}\end{array}$ & -- & $\begin{array}{l}\text { In the first } 24 \mathrm{~h} \text {, higher mean TOR (response } \\
\text { of } \mathrm{P}_{\mathrm{bt}} \mathrm{O}_{2} \text { to changes in arterial } \mathrm{PO}_{2} \text { ) was } \\
\text { associated with worse outcome (GOS) at six } \\
\text { months }\end{array}$ \\
\hline $\begin{array}{l}\text { Meixensberger, et al.; } \\
2003 \text { (J Neurol } \\
\text { Neurosurg Psychiatry) }\end{array}$ & TBI & $\begin{array}{l}53\left(\mathrm{P}_{\mathrm{bt}} \mathrm{O}_{2}\right. \\
\text { group }), 40 \\
\text { (ICP/CPP } \\
\text { group) }\end{array}$ & $\mathrm{P}_{\mathrm{bt}} \mathrm{O}_{2}$ & $<10 \mathrm{mmHg}$ & $\begin{array}{l}\text { More patients with ICP/CPP-guided, as opposed } \\
\text { to } \mathrm{P}_{\mathrm{bt}} \mathrm{O}_{2} \text {-guided therapy, had significantly } \\
\text { decreased } \mathrm{P}_{\mathrm{bt}} \mathrm{O}_{2} \text {, but there was no significant } \\
\text { difference in outcome between the two groups }\end{array}$ \\
\hline $\begin{array}{l}\text { Meixensberger, et al.; } \\
2003 \text { (Neurol Res) }\end{array}$ & $\mathrm{SAH}$ & 42 & $\mathrm{P}_{\mathrm{bt}} \mathrm{O}_{2}$ & $<10 \mathrm{mmHg}$ & $\begin{array}{l}\text { For total monitoring time and last day of } \\
\text { monitoring, but not other periods of monitoring } \\
\text { (e.g., total monitoring time without last two days } \\
\text { or second to last monitoring day), there was a } \\
\text { significant difference in } \mathrm{P}_{\mathrm{bt}} \mathrm{O}_{2} \text { in nonsurvivors } \\
\text { (GOS 1) versus survivors (GOS 3-5) }\end{array}$ \\
\hline $\begin{array}{l}\text { Meixensberger, et al.; } \\
2004\end{array}$ & TBI & 40 & $\mathrm{P}_{\mathrm{bt}} \mathrm{O}_{2}$ & $<15 \mathrm{mmHg}$ & $\begin{array}{l}\text { Patients with } \mathrm{P}_{\mathrm{bt}} \mathrm{O}_{2}<15 \mathrm{mmHg} \text { had worse } \\
\text { outcome in memory, speech, and intelligence } \\
\text { testing }\end{array}$ \\
\hline Stiefel, et al.; 2005 & TBI & $\begin{array}{l}28\left(\mathrm{P}_{\mathrm{bt}} \mathrm{O}_{2}\right. \\
\text { group), } 25 \\
\text { (ICP/CPP } \\
\text { group) }\end{array}$ & $\mathrm{P}_{\mathrm{bt}} \mathrm{O}_{2}$ & $<25 \mathrm{mmHg}$ & $\begin{array}{l}\text { Patients with } \mathrm{P}_{b t} \mathrm{O}_{2} \text { monitoring had } \\
\text { significantly reduced mortality rate of } 25 \% \\
\text { compared to } 44 \% \text { in patients with conventional } \\
\text { ICP and CPP monitoring (historical controls) }\end{array}$ \\
\hline Stiefel, et al.; 2006 & TBI & 25 & $\mathrm{P}_{\mathrm{bt}} \mathrm{O}_{2}$ & $<10,20 \mathrm{mmHg}$ & $\begin{array}{l}\text { Despite optimal ICP/CPP levels, } 47 \% \text { of } \\
\text { patients had } \mathrm{P}_{b t} \mathrm{O}_{2}<20 \mathrm{mmHg} \text { and } 21 \% \text { had } \\
\mathrm{P}_{\mathrm{bt}} \mathrm{O}_{2}<10 \mathrm{mmHg} \text {, and mortality rate is higher } \\
\text { in patients with reduced } \mathrm{P}_{\text {bt }} \mathrm{O}_{2}\end{array}$ \\
\hline Jaeger, et al.; 2007 & $\mathrm{SAH}$ & 67 & $\begin{array}{l}\mathrm{P}_{\mathrm{bt}} \mathrm{O}_{2} \\
\mathrm{IORx}\end{array}$ & -- & $\begin{array}{l}\text { The index of } \mathrm{P}_{b t} \mathrm{O}_{2} \text { pressure reactivity (ORx) } \\
\text { was significantly higher in the delayed cerebral } \\
\text { infarction group ( } 20 \text { patients), and ORx values } \\
\text { on SAH Day } 5 \text { and } 6 \text { carried predictive value } \\
\text { for the occurrence of delayed infarction }\end{array}$ \\
\hline
\end{tabular}


homogeneous white matter may mitigate this to some degree. Finally, placement of the probe involves an invasive procedure, albeit one that has been associated with relatively few complications of hemorrhage or infection even when compared with routine ICP monitoring using a ventricular catheter. ${ }^{[13]}$ Future clinical uses of $\mathrm{P}_{\mathrm{bt}} \mathrm{O}_{2}$ monitoring include additional investigations evaluating patients with hemorrhagic stroke $^{[15,37-39]}$ or brain death. ${ }^{[40,41]}$

\section{Jugular bulb venous oxygen saturation}

Measurement of the venous oxygen saturation in the jugular bulb as blood is exiting the brain provides a measure of global cerebral oxygen delivery. It also provides a way to estimate the global relationship between CBF and metabolism, with the goal of detecting cerebral hypoperfusion or hyperperfusion and thereby preventing and treating secondary ischemic brain injury. ${ }^{[1,7,8,13,42,43]} \mathrm{SjvO}_{2}$ is measured with a catheter that is placed by retrograde cannulation of the internal jugular vein until the catheter is at or near the jugular bulb, usually at the first to second cervical vertebrae and above the level where contamination from extracranial venous blood may occur. ${ }^{[42,44,45]}$ Commercially available catheters have a fiberoptic sensor that continuously measures the blood oxygen saturation, and a small lumen from which blood can be withdrawn for venous blood gas testing. This allows calibration of the catheter as well as calculation of the venous blood oxygen content $\left(\mathrm{C}_{\mathrm{v}} \mathrm{O}_{2}\right)$ and subsequently the cerebral arteriovenous oxygen difference $\left(\mathrm{AVDO}_{2}\right)$. As with $\mathrm{P}_{\mathrm{bt}} \mathrm{O}_{2}$ measurements, whether to cannulate the injured or uninjured side remains a topic of debate; our approach is to cannulate the dominant jugular vein if not limited by neck or other injuries. ${ }^{[42,45]}$ The accuracy of $\mathrm{SjvO}_{2}$ monitors has been confirmed by several studies. ${ }^{[42,44,45]}$ Complications from $\mathrm{SjvO}_{2}$ monitoring are rare, but include carotid puncture, thrombosis, infection, and hematoma formation.

$\mathrm{SjvO}_{2}$ is inversely related to the $\mathrm{AVDO}_{2}$. If the cerebral $\mathrm{AVDO}_{2}$ increases because the brain is extracting more oxygen, then the $\mathrm{SjvO}_{2}$ decreases, and vice versa. The normal $\mathrm{SjvO}_{2}$ level is approximately $60 \%$, although in brain injured patients it may be somewhat higher. While the precise $\mathrm{SjvO}_{2}$ threshold for cerebral ischemia may vary depending on the brain's ability to extract oxygen, an $\mathrm{SjvO}_{2}$ of $<50 \%$ for greater than 10 min has generally been considered to represent an ischemic desaturation. ${ }^{[46]}$ High $\mathrm{SjvO}_{2}$ levels may reflect hyperemia (typically $>90 \%$ ) or an inability of the brain to extract oxygen due to metabolic depression from sedative agents, poor oxygen unloading (e.g. sickle cell disease), or severe brain injury. ${ }^{[13]}$ It should be noted that in certain situations, using $\mathrm{SjvO}_{2}$ as a surrogate for $\mathrm{AVDO}_{2}$ may be problematic. $\mathrm{SjO}_{2}$ may be influenced by hemoglobin levels and $\mathrm{SjvO}_{2}$ may not reflect changes in cerebral oxygen extraction when extraction is intrinsically impaired or large areas of brain are already infarcted. ${ }^{[13,47]}$ It has been suggested that continuous, as opposed to intermittent, $\mathrm{SjvO}_{2}$ monitoring is more effective in detecting significant changes in $\mathrm{SjvO}_{2}$ levels. ${ }^{[48]}$ Causes of low $\mathrm{SjvO}_{2}$ include low CBF, low CPP, fever, and seizures. $\mathrm{SjvO}_{2}$ monitoring has been used most commonly in patients with TBI or SAH for detection of reduced cerebral perfusion and by some to titrate hyperventilation in patients with increased ICP; other clinical applications include detecting arterio-venous fistulas and perioperative monitoring. An important caveat to $\mathrm{SjvO}_{2}$ monitoring is that because it is a global monitor, regional ischemic changes may not be detected, and a relatively large volume of tissue must be affected before the $\mathrm{SjvO}_{2}$ level drops significantly. ${ }^{[8,13]}$

Several studies have investigated the association between $\mathrm{SjvO}_{2}$ monitoring and clinical outcome [Table 1]. Both abnormally high and low $\mathrm{SjvO}_{2}$ levels have been associated with poor clinical outcome in TBI patients..$^{[46,49-51]}$ Early desaturations were most common in the first day post-TBI, and $90 \%$ of patients with multiple early desaturations had a poor clinical outcome, compared to $55 \%$ of patients without desaturations. ${ }^{[50]}$ In one study of continuous $\mathrm{SjvO}_{2}$ monitoring in 177 TBI patients, those with one or more episodes of desaturation had a higher likelihood of poor clinical outcome. ${ }^{[52]}$ In another study in which historical controls were used to compare CPP-directed therapy versus CPP and $\mathrm{SjvO}_{2}$-directed therapy in a total of 353 patients, the $\mathrm{SjvO}_{2}$ group had a significantly better outcome at six months. ${ }^{[43]}$ Finally, $\mathrm{SjvO}_{2}$ monitoring was used in a randomized trial comparing CBF-directed therapy versus ICP-directed therapy in patients with TBI. Overall, there was a significant decrease in the number of $\mathrm{SjvO}_{2}$ desaturations in the CBF group (30\% versus $51 \%$ in the $\mathrm{CBF}$ group). However, there was no difference in long-term clinical outcome, perhaps due to a four-fold increase in incidence of acute respiratory distress syndrome (ARDS) in the CBF-treated patients. [52] This randomized trial has provided important clarification that continuous monitoring of cerebral oxygenation can potentially be used to titrate aggressive systemic interventions designed to improved cerebral perfusion. These and other studies demonstrate a clear relationship between abnormal $\mathrm{SjvO}_{2}$ levels and neurological outcome, but further randomized, prospective studies are needed to determine the optimal use of $\mathrm{SjvO}_{2}$-directed therapy to improve outcome. ${ }^{[42]}$ Future directions for $\mathrm{SjvO}_{2}$ monitoring include monitoring patients with other neurovascular or cardiac disorders and learning how to use $\mathrm{SjvO}_{2}$ monitoring in the context of multi-modality monitoring. ${ }^{[42,53]}$ 


\section{Cerebral microdialysis}

Cerebral microdialysis is a neuromonitoring method that utilizes the capillary technique to measure the concentration of chemicals found in the brain parenchyma, with the goal of detecting neurochemical changes indicative of primary and secondary brain injury. ${ }^{[3,7,28,54]}$ The most commonly used system is the CMA600 microdialysis analyzer (CMA Micordialysis, Stockholm, Sweden); this system allows for semicontinuous measurement at the bedside of numerous parameters including glucose, glutamate, lactate, pyruvate, and glycerol concentrations. ${ }^{[28,54]}$ The microdialysis catheter consists of a fine tube within a semi-permeable dialysis membrane that allows for diffusion of molecules from the extracellular space along the catheter and into a small vial which is placed in the microdialysis analyzer. The catheter is inserted via a burr hole, often alongside $\mathrm{P}_{\mathrm{bt}} \mathrm{O}_{2}$ or ICP monitors. Ideally the microdialysis catheter is placed in the penumbra of the injured area or normal brain, but not directly in the injured brain. ${ }^{[7,55,56]}$ "Mock cerebrospinal fluid (CSF)" is instilled at a slow rate into the microdialysis catheter and then microdialysate is collected in a microvial. This process usually takes 20-30 min, resulting in some delay between real-time events and determined values. Also, microdialysis analysis is usually done intermittently (often hourly), which must be taken into consideration when interpreting microdialysis values. Complications from or detractions to cerebral microdialysis include detection of only focal changes in cerebral metabolism, difficulty in comparing quantitative values due to different catheter lengths and perfusate rates, disruption in brain tissue resulting in gliosis, spreading cortical depression, reduced CBF, flow-metabolism uncoupling, and hemorrhage. ${ }^{[28,54]}$ Another important limitation to microdialysis is the variability of results based on the location of the probe (in injured tissue, normal tissue, or areas of penumbra), bringing into debate the ideal location for catheter placement. ${ }^{[57]}$

Substances that are regularly measured with cerebral microdialysis include glucose, a decrease of which may signify reduced cerebral perfusion, the lactate/pyruvate ratio and glutamate, which may reflect ischemic changes, and glycerol, which may indicate cell membrane breakdown. Several other neurotransmitters, energy-related metabolites, and markers of brain injury have been measured with cerebral microdialysis, and their clinical relevance remains under investigation..$^{[7,28,54]}$ Although cerebral microdialysis has been largely used as a research tool, recently, the clinical utility of microdialysis has been recognized in the management of TBI, SAH, ischemic and hemorrhagic stroke, as well as perioperatively. ${ }^{[6,58-60]}$ A recent consensus meeting on cerebral microdialysis recommended its use in cases of severe TBI which also require ICP/CPP monitoring. ${ }^{[28,54,61]}$ Pathologic alterations in cerebral microdialysate have been correlated to changes in other metabolic parameters, including $\mathrm{P}_{\mathrm{bt}} \mathrm{O}_{2}, \mathrm{SjvO}_{2}$, ICP, blood pressure, hypoxia, and CBF as measured by xenon CT or oxygen extraction fraction as measured by PET ${ }^{[26-28,61-66]}$ and have also been reported during nonconvulsive seizures. ${ }^{[56]}$ Finally, TBI and SAH patients with poor clinical outcome have been shown to have elevated levels of neurotransmitters, elevated lactate/pyruvate ratios, and abnormal lactate and glutamate levels. ${ }^{[39,62,63]}$ One of the largest studies using microdialysis included 126 TBI patients and showed a correlation between increased lactate/glucose ratio and lactate levels and increased mortality rates, as well as $\mathrm{SjvO}_{2}$ desaturations. ${ }^{[27]}$ Other groups have suggested that microdialysis can provide useful information regarding glucose management in critically ill neurological patients and that alterations in cerebral metabolism detected by microdialysis may be independent of other parameters such as CPP. ${ }^{[6,56,64]}$ Because of the lack of randomized trials using microdialysis, further study is needed to determine the utility of cerebral microdialysis in consistently detecting secondary brain injury and how it may direct prospective management to improve outcome.

\section{Cerebral blood flow}

Cerebral blood flow has historically been considered as the most important physiologic parameter in the setting of brain injury, as CBF reflects delivery of substrate to tissue. ${ }^{[13]}$ Normal average CBF in the human is approximately $55 \mathrm{ml} / 100 \mathrm{~g}$ (of brain)/min, but actual values may vary widely across grey and white matter. The ischemic threshold for CBF is approximately $18 \mathrm{ml} / 100 \mathrm{~g} / \mathrm{min}$, with $10 \mathrm{ml} / 100 \mathrm{~g} /$ min often considered the threshold for irreversible injury. CBF is influenced by mean arterial pressure, ICP, and the partial pressure of carbon dioxide and oxygen. These relationships bring forth the important principle of CBF and cerebral metabolic coupling, where $\mathrm{CMRO}_{2}$ is directly related to $\mathrm{CBF}$ and $\mathrm{AVDO}_{2}{ }^{[65]}$ Historically, CBF was one of the first cerebral physiologic parameters to be measured and numerous techniques have been used for its measurement. However, only recently have commercially available continuous CBF neuromonitoring tools become available which may also be of practical use in the neurological intensive care unit.

Two such techniques are thermal diffusion flowmetry (TDF) and laser Doppler flowmetry (LDF). TDF is based on the principle of thermal conductivity of cortical tissue, where the temperature difference between two Silastic probes is detected and converted to quantitative CBF. ${ }^{[13,66,67]}$ Commercially available TDF microprobes include the QFlow 500 Probe and Bowman Perfusion 
Monitor (Hemedex Inc., Cambridge, MA, USA) and the Saber Cerebral Blood Flow Monitoring System (Flowtronics Inc., Phoenix, AZ, USA). Studies have found that CBF measured by thermal diffusion flowmetry correlates with CBF measured by other methods such as xenon CT. However, current TDF probes provide only a single focal CBF measurement from the area near the probe and remain less reliable than other conventional measures of CBF, tending to give higher measurements. ${ }^{[68-71]}$ Inaccurate measurements can also occur in the case of artifact after placement, large surface vessels, and loss of tissue contact; there is also concern of reliability of measurements and perhaps even safety in the context of fever.

Laser Doppler flowmetry involves a probe which is directly inserted into the brain parenchyma or over the surface of the brain, and is able to detect density measurements of moving blood, thereby providing momentary percentage changes in local CBF. ${ }^{[8]} \mathrm{LDF}$ does not provide absolute quantitative values of CBF, but rather relative change. This limits its utility in the context of neuromonitoring. A few studies have demonstrated correlation of LDF measurements to CPP as well as other conventional measures of $\mathrm{CBF}^{[72,73]}$

Another different and important noninvasive technique for continuous or intermittent measurement of CBF is transcranial Doppler ultrasonography (TCD). TCD measures flow velocities in large intracranial vessels and allows for detection of changes in CBF; it is most widely used for detection of vasospasm, but has the potential for other clinical applications..$^{[7,13]}$

Although the focus of modern neuromonitoring is to continuously monitor cerebral physiologic and metabolic parameters to allow for timely management decisions, several intermittent neuroimaging techniques used to measure global changes in CBF are worthy of mention. One such technique is dynamic perfusion computed tomography (CT) or CT perfusion (CTP), where infusion of iodinated contrast and the concurrent acquisition of images using a helical CT multislice scanner in cine mode allow for the measurement of CBF, cerebral blood volume (CBV), and mean transit time (MTT). This technique, which is relatively fast and can be performed on most helical CT scanners, has many potential clinical uses including prognostication in TBI and detection of hypoperfused regions in TBI as well as SAH. ${ }^{[9]}$ Furthermore, preliminary studies have correlated MTT measured by CTP to $\mathrm{P}_{b t} \mathrm{O}_{2}$ in TBI patients, demonstrating the correlation between metabolic and physiologic measures in brain injury [Figure 3]. ${ }^{[18]}$ Stable xenon CT has also had substantial use in the measurement of regional and global CBF. This technique utilizes inhaled nonradioactive xenon and concurrent acquisition of CT images; CBF is then calculated using the Kety-Schmidt equation. With the advent of portable CT machines, CTP and xenon CT may
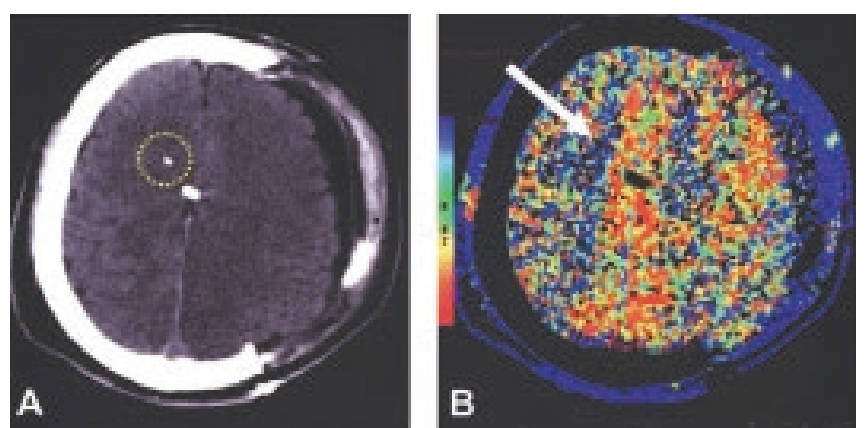

Figure 3: Representative non-contrast head computed tomography (CT) scan and CT perfusion scan in a patient with traumatic brain injury who underwent hemicraniectomy, demonstrating the relationship between $\mathrm{P}_{\mathrm{bt}} \mathrm{O}_{2}$ and CBF. (A) Non-contrast head CT showing the tip of a brain tissue oxygen probe (within dotted circle) in right hemispheric white matter; the midline white attenuation is a ventriculostomy catheter. (B) CT perfusion scan color map of mean transit time (MTT); blue indicates the slowest MTT on the reference bar. Arrow points to the tip of the oxygen probe. Figure demonstrates reduced MTT on the side of the hemicraniectomy, which has been shown to correlate with increased $\mathrm{P}_{\mathrm{bt}} \mathrm{O}_{2}$ levels. (From: Hemphill JC, III, Smith WS, Sonne DC, Morabito D, Manley GT. Relationship between brain tissue oxygen tension and CT perfusion: Feasibility and initial results. AJNR Am J Neuroradiol. 2005;26: 1095-1100, copyrighted by American Society of Neuroradiology)

potentially see expanding roles as neuromonitoring tools in the neurological intensive care unit. Finally, SPECT (single photon emission computerized tomography) and PET (positron emission tomography) provide images of quantitative cerebral perfusion and metabolic parameters ( $\mathrm{CBF}, \mathrm{CMRO}_{2}$, etc.), but are limited by lengthy studies, the necessity to transport sometimes unstable patients, and cumbersome technology which make them of limited utility as practical neuromonitoring tools..$^{[9]}$

\section{Interpreting data for advanced neuromonitoring}

Even as monitoring of the brain has advanced substantially since the origins of critical care in the 1960s, the manner in which intensive care unit physiological data has been collected and analyzed has changed little. This has created a disconnect that is magnified by the substantial increase in continuous physiological data that is generated by new advanced neuromonitors. How to manage all the data is a major question from clinicians considering integrating advanced neuromonitoring devices into clinical patient care. This question is only beginning to be addressed.

The varying relationships found between specific parameters such as CPP, and CBF, $\mathrm{P}_{\mathrm{bt}} \mathrm{O}_{2}$, ICP, $\mathrm{F}_{\mathrm{i}} \mathrm{O}_{2}$ in differing studies suggest that there are likely complex multivariate relationships between physiological variables. This makes intuitive sense but until recently has been difficult to investigate because of limitations in intensive care data acquisition and analysis. Recent studies have suggested that derived measures such as PRx (pressure reactivity index), ORx (oxygen reactivity index), and VS burden (area under the curve for a specific physiologic vital sign such as temperature or blood pressure) may be more informative than raw data and thresholds alone. ${ }^{[1,16,74-77]}$ However, this type of 
analysis requires improved methods of electronic data acquisition. Currently, most systems are locally made solutions, but some commercial systems are now being developed. ${ }^{[16]}$

Consideration is also being given to novel methods of integrating this complex multiparameter-based physiological data. In the fields of genetics and genomics, advanced informatics and statistical methods have been developed to deal with the large volume of data derived from microarrays. In many ways, the continuous multiparameter time-series physiological data in neurocritical care is analogous. Considered tools include using neural network modeling to determine the interrelationships between different measured parameters, ${ }^{[78]}$ using multivariable regression techniques to assess the impact of several factors on one parameter, ${ }^{[79]}$ and using hierarchical cluster techniques for neuromonitoring data analysis in order to construct physiologic data profiles to classify patients for diagnostic and treatment purposes. ${ }^{[80,81]}$ One novel approach has used self-organizing heat maps, a tool used in genetic bioinformatics, to assess association between various physiological parameters and determine how they cluster across patients. ${ }^{[80,81]}$ While the clinical utility of these advanced analyses remains to be clarified, these efforts represent an important first step in harnessing the large amounts of data generated by advanced neuromonitoring. Advances in real time, userfriendly data analysis and presentation must accompany advances in neuromonitoring device development in order to truly move individualized patient-tailored care forward in the neurointensive care unit.

\section{Conclusions}

With the advent of commercially available neuromonitoring techniques which can be routinely used in neurointensive care units, identifying the clinical utility for individual monitors and the complementary roles different techniques might play in multi-modality monitoring has become an increasing priority. As the ultimate goal of neuromonitoring is to assess neurological function and help predict as well as improve outcome, an important next step is to move beyond observational studies and conduct prospective, randomized studies to understand how goal-directed therapy can directly affect outcome in various disorders. ${ }^{[10]}$ Finally, an essential future direction for the field of neuromonitoring is to address how to integrate this complex body of data, with the ultimate goal of translation to the bedside care of patients in the neurointensive care unit. ${ }^{[80]}$

\section{References}

1. Dunn IF, Ellegala DB, Kim DH, Litvack ZN, Neuromonitoring in neurological critical care: Neuromonitoring in neurological critical care. Neurocrit Care 2006;4:83-92.

2. Suarez JI. Outcome in neurocritical care: Advances in monitoring and treatment and effect of a specialized neurocritical care team. Crit Care Med 2006;34:S232-8.

3. De Georgia MA, Deogaonkar A. Multimodal monitoring in the neurological intensive care unit. Neurologist 2005;11:45-54.

4. The Brain Trauma Foundation. The American Association of Neurological Surgeons. The Joint Section on Neurotrauma and Critical Care: Guidelines for cerebral perfusion pressure. J Neurotrauma 2000;17:507-11.

5. The Brain Trauma Foundation. The American Association of Neurological Surgeons. The Joint Section on Neurotrauma and Critical Care: Indications for intracranial pressure monitoring. J Neurotrauma 2000;17:479-91.

6. Vespa PM. Multimodality monitoring and telemonitoring in neurocritical care: From microdialysis to robotic telepresence. Curr Opin Crit Care 2005; $11: 133-8$.

7. Timofeev I, Gupta A. Monitoring of head injured patients. Curr Opin Anaesthesiol 2005;18:477-83.

8. Alvarez del Castillo M. Monitoring neurologic patients in intensive care. Curr Opin Crit Care 2001;7:49-60.

9. Wintermark M, Sesay M, Barbier E, Borbely K, Dillon WP, Eastwood JD, et al. Comparative overview of brain perfusion imaging techniques. Stroke 2005;36:e83-99.

10. Rose JC, Neill TA, Hemphill JC 3rd. Continuous monitoring of the microcirculation in neurocritical care: An update on brain tissue oxygenation. Curr Opin Crit Care 2006;12:97-102.

11. Mulvey JM, Dorsch NW, Mudaliar Y, Lang EW. Multimodality monitoring in severe traumatic brain injury: The role of brain tissue oxygenation monitoring. Neurocrit Care 2004;1:391-402.

12. Hoelper BM, Alessandri B, Heimann A, Behr R, Kempski O. Brain oxygen monitoring: In-vitro accuracy, long-term drift and responsetime of Licox- and Neurotrend sensors. Acta Neurochir (Wien) 2005;147:767-74.

13. Valadka AB, Andrews BT. Neurotrauma: Evidence-based answers to common questions. New York: Theme; 2005. p. 288.

14. Haitsma IK, Maas AI. Advanced monitoring in the intensive care unit: Brain tissue oxygen tension. Curr Opin Crit Care 2002;8:115-20.

15. Hemphill JC 3rd, Morabito D, Farrant M, Manley GT. Brain tissue oxygen monitoring in intracerebral hemorrhage. Neurocrit Care $2005 ; 3: 260-70$.

16. Johnston AJ, Steiner LA, Coles JP, Chatfield DA, Fryer TD, Smielewski $\mathrm{P}$, et al. Effect of cerebral perfusion pressure augmentation on regional oxygenation and metabolism after head injury. Crit Care Med 2005;33:189-95; discussion 255-7.

17. Gopinath SP, Valadka AB, Uzura M, Robertson CS. Comparison of jugular venous oxygen saturation and brain tissue Po2 as monitors of cerebral ischemia after head injury. Crit Care Med 1999;27:2337-45.

18. Hemphill JC 3rd, Smith WS, Sonne DC, Morabito D, Manley GT. Relationship between brain tissue oxygen tension and CT perfusion: Feasibility and initial results. AJNR Am J Neuroradiol 2005;26:1095-100.

19. Hemphill JC 3rd, Knudson MM, Derugin N, Morabito D, Manley GT. Carbon dioxide reactivity and pressure autoregulation of brain tissue oxygen. Neurosurgery 2001;48:377-83.

20. Manley GT, Pitts LH, Morabito D, Doyle CA, Gibson J, Gimbel M, et al. Brain tissue oxygenation during hemorrhagic shock, resuscitation, and alterations in ventilation. J Trauma 1999;46:261-7.

21. Unterberg AW, Kiening KL, Hartl R, Bardt T, Sarrafzadeh AS, Lanksch WR. Multimodal monitoring in patients with head injury: Evaluation of the effects of treatment on cerebral oxygenation. J Trauma 1997;42:S32-7.

22. Schneider GH, Sarrafzadeh AS, Kiening KL, Bardt TF, Unterberg AW, Lanksch WR. Influence of hyperventilation on brain tissue-PO2, $\mathrm{PCO} 2$, and $\mathrm{pH}$ in patients with intracranial hypertension. Acta Neurochir Suppl 1998;71:62-5.

23. van Santbrink H, vd Brink WA, Steyerberg EW, Carmona Suazo JA, Avezaat CJ, Maas AI. Brain tissue oxygen response in severe traumatic brain injury. Acta Neurochir (Wien) 2003;145:429-38. 
24. Filippi R, Reisch R, Mauer D, Perneczky A. Brain tissue pO2 related to SjvO2, ICP, and CPP in severe brain injury. Neurosurg Rev 2000;23:94-7.

25. Sarrafzadeh AS, Sakowitz OW, Callsen TA, Lanksch WR, Unterberg AW. Bedside microdialysis for early detection of cerebral hypoxia in traumatic brain injury. Neurosurg Focus 2000;9:e2.

26. Sarrafzadeh AS, Sakowitz OW, Callsen TA, Lanksch WR, Unterberg AW. Detection of secondary insults by brain tissue $\mathrm{pO} 2$ and bedside microdialysis in severe head injury. Acta Neurochir Suppl 2002;81:319-21

27. Goodman JC, Valadka AB, Gopinath SP, Uzura M, Robertson CS. Extracellular lactate and glucose alterations in the brain after head injury measured by microdialysis. Crit Care Med 1999;27:1965-73.

28. Johnston AJ, Gupta AK. Advanced monitoring in the neurology intensive care unit: microdialysis. Curr Opin Crit Care 2002;8:121-7.

29. Valadka AB, Gopinath SP, Contant CF, Uzura M, Robertson CS. Relationship of brain tissue PO2 to outcome after severe head injury. Crit Care Med 1998;26:1576-81.

30. van den Brink WA, van Santbrink H, Steyerberg EW, Avezaat CJ, Suazo JA, Hogesteeger C, et al. Brain oxygen tension in severe head injury. Neurosurgery 2000;46:868-76.

31. Bardt TF, Unterberg AW, Hartl R, Kiening KL, Schneider GH, Lanksch WR. Monitoring of brain tissue PO2 in traumatic brain injury: Effect of cerebral hypoxia on outcome. Cerebrovasc Brain Metab Rev 1998;71:153-6.

32. Kiening KL, Hartl R, Unterberg AW, Schneider GH, Bardt T, Lanksch WR. Brain tissue pO2-monitoring in comatose patients: Implications for therapy. Neurol Res 1997;19:233-40.

33. Stiefel MF, Spiotta A, Gracias VH, Garuffe AM, Guillamondegui O, Maloney-Wilensky E, et al. Reduced mortality rate in patients with severe traumatic brain injury treated with brain tissue oxygen monitoring. J Neurosurg 2005;103:805-11.

34. Meixensberger J, Jaeger M, Vath A, Dings J, Kunze E, Roosen K. Brain tissue oxygen guided treatment supplementing ICP/CPP therapy after traumatic brain injury. J Neurol Neurosurg Psychiatry $2003 ; 74: 760-4$

35. Meixensberger J, Renner C, Simanowski R, Schmidtke A, Dings J, Roosen K. Influence of cerebral oxygenation following severe head injury on neuropsychological testing. Neurol Res 2004;26:414-7.

36. Jaeger M, Schuhmann MU, Soehle M, Nagel C, Meixensberger J. Continuous monitoring of cerebrovascular autoregulation after subarachnoid hemorrhage by brain tissue oxygen pressure reactivity and its relation to delayed cerebral infarction. Stroke 2007;38:981-6.

37. Vath A, Kunze E, Roosen K, Meixensberger J. Therapeutic aspects of brain tissue pO2 monitoring after subarachnoid hemorrhage. Acta Neurochir Suppl 2002;81:307-9.

38. Meixensberger J, Vath A, Jaeger M, Kunze E, Dings J, Roosen K. Monitoring of brain tissue oxygenation following severe subarachnoid hemorrhage. Neurol Res 2003;25:445-50.

39. Kett-White R, Hutchinson PJ, Al-Rawi PG, Gupta AK, Pickard JD, Kirkpatrick PJ. Adverse cerebral events detected after subarachnoid hemorrhage using brain oxygen and microdialysis probes. Neurosurgery 2002;50:1213-21.

40. Palmer S, Bader MK. Brain tissue oxygenation in brain death. Neurocrit Care 2005;2:17-22.

41. Smith ML, Counelis GJ, Maloney-Wilensky E, Stiefel MF, Donley K, LeRoux PD. Brain tissue oxygen tension in clinical brain death: A case series. Neurol Res 2007;29:755-9.

42. Macmillan CS, Andrews PJ. Cerebrovenous oxygen saturation monitoring: Practical considerations and clinical relevance. Intensive Care Med 2000;26:1028-36.

43. Cruz J. The first decade of continuous monitoring of jugular bulb oxyhemoglobinsaturation: Management strategies and clinical outcome. Crit Care Med 1998;26:344-51.

44. Coplin WM, O'Keefe GE, Grady MS, Grant GA, March KS, Winn HR, et al. Accuracy of continuous jugular bulb oximetry in the intensive care unit. Neurosurgery 1998;42:533-9.

45. Coplin WM, O'Keefe GE, Grady MS, Grant GA, March KS, Winn HR, et al. Thrombotic, infectious, and procedural complications of the jugular bulb catheter in the intensive care unit. Neurosurgery
1997;41:101-7.

46. Robertson CS, Gopinath SP, Goodman JC, Contant CF, Valadka AB, Naravan RK. SjvO2 monitoring in head-injured patients. J Neurotrauma 1995;12:891-6.

47. Zanier ER, Rossi S, Conte V, Colombo A, Nicolini R, Caironi P, et al. The ratio between arterio-venous PCO2 difference and arterio-jugular oxygen difference as estimator of critical cerebral hypoperfusion. Minerva Anestesiol 2006;72:543-9.

48. Latronico N, Beindorf AE, Rasulo FA, Febbrari P, Stefini R, Cornali C, et al. Limits of intermittent jugular bulb oxygen saturation monitoring in the management of severe head trauma patients. Neurosurgery 2000;46:1131-8

49. Macmillan CS, Andrews PJ, Easton VJ. Increased jugular bulb saturation is associated with poor outcome in traumatic brain injury. J Neurol Neurosurg Psychiatry 2001;70:101-4.

50. Gopinath SP, Robertson CS, Contant CF, Haves C, Feldman Z, Narayan RK, et al. Jugular venous desaturation and outcome after head injury. J Neurol Neurosurg Psychiatry 1994;57:717-23.

51. Cormio M, Valadka AB, Robertson CS. Elevated jugular venous oxygen saturation after severe head injury. J Neurosurg 1999;90:9-15.

52. Robertson CS, Valadka AB, Hannay HJ, Contant CF, Gopinath SP, Cormio M, et al. Prevention of secondary ischemic insults after severe head injury. Crit Care Med 1999;27:2086-95.

53. Buunk G, van der Hoeven JG, Meinders AE. Prognostic significance of the difference between mixed venous and jugular bulb oxvgen saturation in comatose patients resuscitated from a cardiac arrest. Resuscitation $1999 ; 41: 257-62$.

54. Hillered L, Vespa PM, Hovda DA. Translational neurochemical research in acute human brain injury: The current status and potential future for cerebral microdialysis. J Neurotrauma 2005;22:3-41.

55. Engstrom M, Polito A, Reinstrup P, Romner B, Ryding E, Ungerstedt U, et al. Intracerebral microdialysis in severe brain trauma: The importance of catheter location. J Neurosurg 2005;102:460-9.

56. Vespa PM, O'Phelan K, McArthur D, Miller C, Eliseo M, Hirt D, et al. Pericontusional brain tissue exhibits persistent elevation of lactate/ pyruvate ratio independent of cerebral perfusion pressure. Crit Care Med 2007;35:1153-60.

57. Nordstrom CH, Reinstrup P, Xu W, Gardenfors A, Ungerstedt U. Assessment of the lower limit for cerebral perfusion pressure in severe head injuries by bedside monitoring of regional energy metabolism. Anesthesiology 2003;98:809-14

58. Unterberg AW, Sakowitz OW, Sarrafzadeh AS, Benndorf G, Lanksch WR. Role of bedside microdialysis in the diagnosis of cerebral vasospasm following aneurysmal subarachnoid hemorrhage. J Neurosurg 2001;94:740-9

59. Saveland H, Nilsson OG, Boris-Moller F, Wieloch T, Brandt L. Intracerebral microdialysis of glutamate and aspartate in two vascular territories after aneurysmal subarachnoid hemorrhage. Neurosurgery $1996 ; 38: 12-9$.

60. Nilsson OG, Brandt L, Ungerstedt U, Saveland H. Bedside detection of brain ischemia using intracerebral microdialysis: Subarachnoid hemorrhage and delayed ischemic deterioration. Neurosurgery 1999;45:1176-84.

61. Bellander BM, Cantais E, Enblad P, Hutchinson P, Nordstrom CH, Robertson $\mathrm{C}$, et al. Consensus meeting on microdialysis in neurointensive care. Intensive Care Med 2004;30:2166-9

62. Gopinath SP, Valadka AB, Goodman JC, Robertson CS. Extracellular glutamate and aspartate in head injured patients. Acta Neurochir Suppl 2000;76:437-8

63. Reinert M, Khaldi A, Zauner A, Doppenberg E, Choi S, Bullock R. High level of extracellular potassium and its correlates after severe head injury: Relationship to high intracranial pressure. J Neurosurg 2000;93:800-7

64. Vespa PM, McArthur D, O'Phelan K, Glenn T, Etchepare M, Kelly $\mathrm{D}$, et al. Persistently low extracellular glucose correlates with poor outcome 6 months after human traumatic brain injury despite a lack of increased lactate: A microdialysis study. J Cereb Blood Flow Metab $2003 ; 23: 865-77$

65. Dunn IF, Ellegala DB, Fox JF, Kim DH. Principles of cerebral oxygenation and blood flow in the neurological critical care unit. 
Neurocrit Care 2006;4:77-82.

66. Carter LP, Weinand ME, Oommen KJ. Cerebral blood flow (CBF) monitoring in intensive care by thermal diffusion. Acta Neurochir Suppl (Wien) 1993;59:43-6.

67. Carter LP. Surface monitoring of cerebral cortical blood flow. Cerebrovase Brain Metab Rev 1991;3:246-61.

68. Vajkoczy P, Roth H, Horn P, Lucke T, Thome C, Hubner U, et al. Continuous monitoring of regional cerebral blood flow: Experimental and clinical validation of a novel thermal diffusion microprobe. J Neurosurg 2000;93:265-74.

69. Sioutos PJ, Orozeo JA, Carter LP, Weinand ME, Hamilton AJ, Williams FC. Continuous regional cerebral cortical blood flow monitoring in head-injured patients. Neurosurgery 1995;36:943-9.

70. Jaeger M, Soehle M, Schuhmann MU, Winkler D, Meixensberger J. Correlation of continuously monitored regional cerebral blood flow and brain tissue oxygen. Acta Neurochir (Wien) 2005;147:51-6.

71. Gopinath SP, Valadka A, Contant CF, Robertson CS. Relationship between global and cortical cerebral blood flow in patients with head injuries. Neurosurgery 1999;44: 1273-8.

72. Lam JM, Hsiang JN, Poon WS. Monitoring of autoregulation using laser Doppler flowmetry in patients with head injury. J Neurosurg $1997 ; 86: 438-45$

73. Miller JI, Chou MW, Capocelli A, Bolognese P, Pan J, Milhorat TH. Continuous intracranial multimodality monitoring comparing local cerebral blood flow, cerebral perfusion pressure, and microvascular resistance. Acta Neurochir Suppl 1998;71:82-4.

74. Barton CW, Hemphill JC 3rd. Cumulative dose of hypertension predicts outcome in intracranial hemorrhage better than American Heart Association guidelines. Acad Emerg Med 2007;14:695-701.
75. Barton CW, Hemphill JC, Morabito D, Manley G. A novel method of evaluating the impact of secondary brain insults on functional outcomes in traumatic brain-injured patients. Acad Emerg Med 2005;12:1-6.

76. Czosnyka M, Smielewski P, Czosnyka Z, Piechnik S, Steiner LA, Schmidt $\mathrm{E}$, et al. Continuous assessment of cerebral autoregulation: Clinical and laboratory experience. Acta Neurochir Suppl 2003;86:581-5.

77. Steiner LA, Czosnyka M, Piechnik SK, Smielewski P, Chatfield D, Menon DK, et al. Continuous monitoring of cerebrovascular pressure reactivity allows determination of optimal cerebral perfusion pressure in patients with traumatic brain injury. Crit Care Med 2002;30:733-8

78. Vath A, Meixensberger J, Dings J, Meinhardt M, Roosen K. Prognostic significance of advanced neuromonitoring after traumatic brain injury using neural networks. Zentralbl Neurochir 2000;61:2-6.

79. Andrews PJ, Sleeman DH, Statham PF, MeQuatt A, Corruble V, Jones $\mathrm{PA}$, et al. Predicting recovery in patients suffering from traumatic brain injury by using admission variables and physiological data: A comparison between decision tree analysis and logistic regression. J Neurosurg 2002;97:326-36.

80. Sorani MD, Hemphill JC 3rd, Morabito D, Rosenthal G, Manley GT. New approaches to physiological informatics in neurocritical care. Neurocrit Care 2007;7:45-52.

81. Nelson DW, Bellander BM, Maccallum RM, Axelsson J, Alm M, Wallin $\mathrm{M}$, et al. Cerebral microdialysis of patients with severe traumatic brain injury exhibits highly individualistic patterns as visualized by cluster analysis with self-organizing maps. Crit Care Med 2004;32:2428-36.

Accepted on 17-09-2008

Source of Support: Nil, Conflict of Interest: None declared. 